\title{
Pemodelan usaha ternak Kambing Senduro menuju penguatan kelembagaan korporasi di Kabupaten \\ Lumajang
}

\author{
Soetriono ${ }^{1}$, Triana Dewi Hapsari ${ }^{1}$, Abdullah Muhlis ${ }^{2,}$ * \\ 1Program Studi Agribisnis, Fakultas Pertanian, Universitas Jember, Jember, 68121 \\ ${ }^{2}$ Program Studi Magister Agribisnis, Fakultas Pertanian, Universitas Jember, Jember, 68121 \\ *Correspondence: abdullahmuhlis28@gmail.com
}

Received: January 28 ${ }^{\text {th }}, 2020$; Accepted: August $8^{\text {th }}, 2020$; Published online: November $26^{\text {th }}, 2020$

\section{Abstrak}

Tujuan: Pedoman pengembangan kawasan pertanian berbasis korporasi petani tercantum dalam Peraturan Menteri Pertanian Republik Indonesia Nomor 18/PERMENTAN/RC.040/4/2018 yang bertujuan untuk memperkuat sistem usaha ternak secara utuh dalam satu manajemen kawasan. Tujuan penelitian ini untuk mengetahui sistem agribisnis dan pemodelan pada usaha ternak Kambing Senduro.

Metode: Penelitian dilakukan pada bulan Agustus 2019 di Kecamatan Senduro Kabupaten Lumajang. Responden terdiri dari peternak berjumlah 15 orang, pedagang pengumpul berjumlah 1 orang dan pemilik Agroindustri Goatzilla berjumlah 1 orang yang ditentukan secara Snowball Sampling. Data dianalisis menggunakan analisis deskriptif, nilai tambah metode Hayami dan margin pemasaran.

Hasil: 1a) Subsistem input produksi terdiri dari bibit, pakan, dan tenaga kerja, 1b) Subsistem usaha ternak terdiri dari pembersihan kandang, pemberian pakan dan penanganan penyakit, 1c) Subsistem pengolahan menjadi susu pasteurisasi, yogurt, dan kefir memiliki nilai tambah yang positif, 1d) Subsistem pemasaran terdiri dari peternak, pedagang pengumpul dan agroindustri, 1e) Subsistem sarana penunjang didukung oleh Pemerintah Daerah Kabupaten Lumajang. 2) Pemodelan pada usaha ternak Kambing Senduro terdiri dari lembaga utama (peternak, kelompok ternak, pedagang pengumpul, agroindustri, dan konsumen) dan lembaga pendukung (dinas pertanian dan perdagangan, perguruan tinggi, serta lembaga keuangan).

Kesimpulan: Sistem agribinis pada usaha ternak Kambing Senduro terdiri dari subsistem input produksi, usaha ternak, pengolahan, pemasaran, dan sarana penunjang, yang dilakukan oleh lembaga utama maupun pendukung yang ada pada pemodelan usaha ternak Kambing Senduro.

Kata Kunci: Kambing senduro; Sistem agribisnis; Pemodelan

\section{Abstract}

Objective: Guidelines for the development of farmer-based farming areas are listed in the Minister of Agriculture Regulation of the Republic of Indonesia Number 18/PERMENTAN/RC.040/4/2018 which aims to strengthen the whole livestock business system in one area management. The purpose of this study was to determine the agribusiness system and modeling in the Senduro Goat Farm. 
Methods: The study was conducted in August 2019 in Senduro Subdistrict, Lumajang Regency. Respondents consisted of 15 farmers, 1 traders and 1 Goatzilla Agroindustry owner, 1 person determined by Snowball Sampling. Data were analyzed using descriptive analysis, the added value of the Hayami method and marketing margins.

Results: 1a) Production input subsystems consisting of seeds, feed, and labor, 1b) Livestock business subsystem consisting of cage cleaning, feeding and disease management, 1c) Processing subsystems into pasteurized milk, yogurt, and kefir have added value positive, 1d) Marketing subsystem consists of farmers, collectors and agro-industry, 1e) Supporting infrastructure subsystem is supported by the Lumajang Regency Government. 2) Modeling of the Senduro Goat livestock business consists of the main institutions (breeders, herds, collectors, agroindustries, and consumers) and supporting institutions (agriculture and trade services, universities, and financial institutions).

Conclusions: The agribinis system in the Senduro Goat livestock business consists of production input subsystems, livestock business, processing, marketing, and supporting facilities, which are carried out by the main and supporting institutions in the modeling of the Senduro Goat livestock business.

Keywords: Senduro goat; Agribusiness system; Modeling

\section{PENDAHULUAN}

Sub sektor peternakan memiliki peran yang strategis dalam pembangunan sektor pertanian, yaitu dalam upaya pemantapan ketahanan pangan untuk memenuhi kebutuhan protein hewani, pemberdayaan ekonomi masyarakat, dan dapat memacu pengembangan wilayah [1]. Pembangunan kawasan agribisnis berbasis peternakan adalah merupakan salah satu alternatif program terobosan yang diharapkan dapat menjawab tantangan dan tuntutan pembangunan peternakan yaitu meningkatkan pendapatan dan kesejahteraan masyarakat [2].

Pedoman pengembangan kawasan pertanian berbasis korporasi petani tercantum dalam Peraturan Menteri Pertanian Republik Indonesia Nomor 18/PERMENTAN/RC.040/4/ 2018 yang bertujuan untuk: 1) meningkatkan nilai tambah serta daya saing wilayah dan komoditas pertanian untuk keberlanjutan ketahanan pangan nasional; 2) memperkuat sistem usahatani secara utuh dalam satu manajemen kawasan; dan 3) memperkuat kelembagaan petani dalam mengakses informasi, teknologi, prasarana dan sarana publik, permodalan serta pengolahan dan pemasaran.

Kawasan peternakan adalah kawasan yang secara khusus diperuntukan untuk kegiatan peternakan [3]. Dikatakan sebagai kawasan peternakan karena ada beberapa hal diantaranya tempat atau lokasi sesuai dengan agroekosistem dan alokasi tata ruang wilayahnya, dibangun dan dikembangkan oleh masyarakat.dalam atau sekitar kawasan tersebut, berbasis komoditas ternak unggulan dan atau komoditas ternak strategis, adanya suatu pengembangan kelompok tani menjadi kelompok pengusaha, ada sebagian besar pendapatan masyarakat berasal dari usaha agribisnis peternakan itu sendiri, harus memiliki prospek pasar yang jelas dan terarah, adanya dukungan dari ketersediaan teknologi yang sesuai dan memadai, memiliki peluang pengembangan atau diversifikasi produk yang tinggi serta adanya didukung oleh kelembagaan dan jaringan [4].

Berdasarkan Keputusan Menteri Pertanian Republik Indonesia Nomor 472/ Kpts/RC.040/4/2018， Kabupaten Lumajang merupakan salah satu Lokasi Kawasan Pertanian Nasional Prioritas Peternakan Kambing. Menurut Manik et al. [5], Kabupaten Lumajang menetapkan kawasan pengembangan agropolitan yang diarahkan pada Kawasan Agropolitan Seroja yang terdiri dari 8 desa yang berada di Kecamatan Senduro dan Kecamatan Pasrujambe yang meliputi Desa Senduro, Desa Kandangtepus, Desa Kandangan, Desa Burno, Desa Argosari, Desa Jambekumbu, Desa Pasrujambe, dan Desa Jambearum. Di Kecamatan senduro merupakan daerah basis ternak kuda, sapi perah, kambing perah, domba, ayam buras, dan ayam pedaging. Populasi kambing di 
Kecamatan Senduro pada tahun 2018 sebanyak 23.788 ekor dimana $96 \%$ atau 22.858 ekor merupakan kambing perah.

Beberapa permasalahan yang dihadapi dalam sektor peternakan kambing perah adalah sebagai berikut: 1) bibit tidak berkualitas, 2) susah mendapatkan hijauan yang berkualitas sehingga asupan nutrisi ternak dari hijauan tidak tercukupi, 3) penyakit ternak menyebabkan kerugian ekonomis, 4) bau prengus membuat masyarakat enggan membeli susu kambing, 5) legalitas izin edar susu masih sulit untuk diakses, 6) anggota kelompok kurang dan belum bisa saling bekerja sama, dan 7) kelompok kurang tersosialisasi dan tujuannya belum jelas [6].

Kecamatan Senduro merupakan salah satu kecamatan yang menjadi sentra peternakan Kambing Senduro di Kabupaten Lumajang. Kambing Senduro adalah kambing perah ras Peranakan Etawah karena merupakan hasil persilangan Jamnapari ras Etawah dengan kambing lokal Senduro [7]. Terdapat beberapa hambatan di sektor on-farm maupun off-farm dalam pengembangan agribisnis Kambing Senduro. Beberapa hambatan yang terjadi di sektor on-farm yaitu terbatasnya pakan hijauan pada musim kemarau dan susu yang tidak memenuhi syarat tidak dibeli agroindustri. Beberapa hambatan yang terjadi di sektor off-farm yaitu harga bakteri untuk membuat olahan susu cukup mahal, alat yang digunakan untuk membuat olahan susu masih sederhana, belum mengurus ijin edar dari BPOM untuk produk susu pasteurisasi, yogurt dan kefir serta pemodalan terbatas. Tujuan penelitian ini untuk mengetahui sistem agribisnis dan pemodelan pada usaha ternak Kambing Senduro.

\section{MATERI DAN METODE}

Penelitian ini menggunakan metode deskriptif analitis yang dilakukan pada bulan Agustus 2019 di Kecamatan Senduro Kabupaten Lumajang. Berdasarkan Keputusan Menteri Pertanian Republik Indonesia Nomor 472/Kpts/RC.040/4/2018, Kabupaten Lumajang merupakan salah satu Lokasi Kawasan Pertanian Nasional Prioritas
Peternakan Kambing. Responden terdiri dari (15 peternak), 2 ketua kelompok ternak, 1 pedagang pengumpul, 1 pemilik Agroindustri Goatzilla dan 1 ekpert dari Badan Perencanaan Pembangunan Daerah yang ditentukan secara Snowball Sampling yaitu satu sampel memberikan informasi lalu menunjuk sampel yang lain hingga seluruh informasi yang dibutuhkan terpenuhi [8]. Teknik pengumpulan data menggunakan metode wawancara. Menurut Rosaliza [9], wawancara merupakan metode ketika subjek dan peneliti bertemu dalam satu situasi dalam proses mendapatkan informasi.

Sistem agribisnis Kambing Senduro terdiri dari subsistem input produksi, usaha ternak, pengolahan, pemasaran dan sarana penunjang. Subsistem input produksi, usaha ternak dan sarana penunjang serta pemodelan usaha ternak Kambing Senduro dianalisis menggunakan analisis deskriptif. Menurut Zellatifanny dan Mudjiyanto [10], penelitian deskriptif merupakan metode penelitian yang berusaha menggambarkan objek atau subyek yang diteliti secara objektif dan bertujuan menggambarkan fakta secara sistematis.

Subsistem pengolahan yaitu mengenai nilai tambah produk olahan susu Kambing Senduro dianalisis menggunakan analisis nilai tambah metode Hayami dengan formulasi sebagai berikut [11].

$$
\mathrm{VA}=\mathrm{NP}-\mathrm{IC}
$$

Keterangan:

VA $=$ Value Added atau Nilai Tambah pada olahan susu Kambing Senduro (Rp/liter bahan baku susu Kambing Senduro)

NP = Nilai Produksi yaitu penjualan hasil olahan susu Kambing Senduro (Rp/liter bahan baku susu Kambing Senduro)

IC = Intermediate Cost yaitu biaya yang menunjang dalam proses produksi selain biaya tenaga kerja (Rp/liter bahan baku susu Kambing Senduro)

Subsistem pemasaran yaitu mengenai margin pemasaran susu Kambing Senduro dianalisis menggunakan analisis margin pemasaran dengan formulasi sebagai berikut [12]. 


$$
\mathrm{MP}=\mathrm{Pr}-\mathrm{Pf}
$$

Dimana:

$\mathrm{MP}=$ Margin pemasaran

$\operatorname{Pr}=$ Harga di tingkat konsumen

Pf = Harga di tingkat produsen

\section{HASIL DAN PEMBAHASAN}

Berdasarkan hasil perhitungan nilai tambah, produk dengan nilai tambah tertinggi hingga terendah yaitu kefir, yogurt, dan susu pasteurisasi. Nilai tambah kefir sebesar Rp. 52.237,79 paling tinggi karena harga produk kefir dua kali lipat harga produk yogurt dan susu pasteurisasi. Nilai tambah yogurt sebesar Rp. 44.773,53 lebih besar daripada nilai tambah susu pasteurisasi karena output yang dihasilkan dua kali lipat dari input yang digunakan. Hasil perhitungan nilai tambah produk olahan susu Kambing Senduro yang lebih rinci disajikan pada Tabel 1.

Berdasarkan hasil perhitungan, nilai margin pemasaran susu Kambing Senduro sebesar Rp. 42.333,33. Lembaga pemasaran dengan share keuntungan tertinggi hingga terendah yaitu agroindustri (39,34\%), peternak $(20,63 \%)$ dan pedagang pengumpul $(2,53 \%)$. Selisih nilai distribusi margin antara agroindustri dan pedagang pengumpul cukup tinggi yaitu 46,37\%, artinya keuntungan yang diperoleh oleh setiap lembaga pemasaran tidak merata. Hasil perhitungan margin pemasaran susu Kambing Senduro yang lebih rinci disajikan pada Tabel 2.

\section{Sistem agribisnis Kambing Senduro di} Kecamatan Senduro, Kabupaten Lumajang

Menurut Wahyuningsih [13], agribisnis merupakan suatu sistem yang terdiri dari subsistem dari mulai pengadaan sarana produksi sampai pemasaran hasil olahan. Berbagai subsistem tersebut membentuk jaringan yang berhubungan satu sama lain sehingga saling tergantung. Bila salah satu subsistem tidak berfungsi maka akan mempengaruhi keseluruhan sistem.

1. Subsistem input produksi

Sarana input produksi Kambing Senduro adalah semua sarana yang

Tabel 1. Nilai tambah produk susu pasteurisasi, yogurt dan kefir (Metode Hayami)

\begin{tabular}{|c|c|c|c|c|}
\hline No. & Variabel & $\begin{array}{c}\text { Susu } \\
\text { Pasteurisasi }\end{array}$ & Yogurt & Kefir \\
\hline \multicolumn{5}{|c|}{ Output, Input dan Harga } \\
\hline 1. & Output (L/proses produksi) & 10,00 & 30,00 & 10,00 \\
\hline 2. & $\begin{array}{l}\text { Input: Susu Kambing Senduro (L/proses } \\
\text { produksi) }\end{array}$ & 10,00 & 15,00 & 10,00 \\
\hline 3. & Input tenaga kerja (Jam/hari) & 1,00 & 2,00 & 1,00 \\
\hline 4. & Faktor konversi [1/2] & 1,00 & 2,00 & 1,00 \\
\hline 5. & Koefisien tenaga kerja [3/2] & 0,10 & 0,13 & 0,10 \\
\hline 6. & Harga produk (Rp/L) & $40.000,00$ & $40.000,00$ & $80.000,00$ \\
\hline 7. & Upah tenaga kerja (Rp/proses produksi) & $25.000,00$ & $25.000,00$ & $25.000,00$ \\
\hline \multicolumn{5}{|c|}{ Penerimaan dan Keuntungan } \\
\hline 8. & $\begin{array}{l}\text { Harga bahan baku: Susu Kambing Senduro } \\
(\operatorname{Rp} / \mathrm{L})\end{array}$ & $13.000,00$ & $13.000,00$ & $13.000,00$ \\
\hline 9. & Harga input lain (Rp/proses produksi) & $12.087,21$ & $22.226,47$ & $14.762,21$ \\
\hline 10 & Nilai output $(\mathrm{Rp} / \mathrm{L})=[4 \times 6]$ & $40.000,00$ & $80.000,00$ & $80.000,00$ \\
\hline \multirow[t]{2}{*}{11.} & a. Nilai tambah $(\mathrm{Rp} / \mathrm{L})=[10-9-8]$ & $14.912,79$ & $44.773,53$ & $52.237,79$ \\
\hline & b. Rasio nilai tambah $(\%)=[11 \mathrm{a} / 10] \times 100$ & 37,28 & 55,97 & 65,30 \\
\hline \multirow[t]{2}{*}{12.} & a. Pendapatan tenaga kerja $(\mathrm{Rp} / \mathrm{L})=[5 \times 7]$ & $2.500,00$ & $3.333,33$ & $2.500,00$ \\
\hline & b. Pangsa tenaga kerja $(\%)=[12 a / 11 a] \times 100$ & 16,76 & 7,44 & 4,79 \\
\hline \multirow[t]{2}{*}{13.} & a. Keuntungan $(\mathrm{Rp} / \mathrm{L})=[11 \mathrm{a}-12 \mathrm{a}]$ & $12.412,79$ & $41.440,19$ & $49.737,79$ \\
\hline & b. Tingkat keuntungan $(\%)=[13 a / 10] \times 100$ & 31,03 & 51,80 & 62,17 \\
\hline
\end{tabular}


dibutuhkan oleh peternak untuk melakukan kegiatan usaha ternaknya. Sarana tersebut terdiri dari bibit, pakan, dan tenaga kerja. Harga bibit Kambing Senduro betina yaitu sekitar Rp. 2.000.000 sd Rp. 4.000.000, sedangkan harga bibit Kambing Senduro jantan yaitu sekitar Rp. 5.000.000 sd Rp. 7.000.000. Sistem penjualan bibit kambing Peranakan Etawa yang merupakan ras dari Kambing Senduro dibedakan menjadi grade A, B, C dan D. Grade A adalah bibit yang mempunyai kualitas super dan harga jual yang lebih tinggi dibandingkan dengan grade lainnya [14].

Menurut Yunus [15], bagi peternak yang berorientasi pada kambing perah harus jeli dalam memilih tanaman yang dapat meningkatkan produksi susu sebagai pakan hijauan seperti daun kaliandra, turi, katuk, dadap, dll. Peternak memperoleh pakan hijauan dari lahan sendiri dan beberapa peternak ada yang membeli dengan harga sekitar Rp. 15.000 sd Rp. 20.000 per ikat. Menurut Moeljanto dan Wiryanta [16], dalam membantu suplai gizi, protein, mineral dan vitamin serta untuk membantu produksi susu, pakan tambahan seperti konsentrat bisa juga digunakan. Ampas tahu, dedak, jagung giling, singkong, bisa diberikan sebagai pengganti konsentrat. Beberapa jenis pakan tambahan yang digunakan peternak antara lain konsentrat, yellow, tumpi, ampas tahu, dan tepung jagung dengan harga masing-masing yaitu sekitar Rp. 1.000 sd Rp. 5.000 per kg. 2 peternak Kambing Senduro dalam menjalankan usaha ternak dibantu tenaga kerja. Tugas dari tenaga kerja antara lain yaitu mencari pakan hijauan, memberi makan, memerah susu, dan membersihkan kandang. Upah yang diterima tenaga kerja per bulan yaitu sekitar Rp. 750.000 dan Rp. 1.200.000.

2. Subsistem usaha ternak

Subsistem usaha ternak yaitu kegiatan ekonomi yang menggunakan sarana dan prasarana ternak untuk menghasilkan produk primer khususnya susu kambing segar. Tahapan yang dilakukan oleh peternak dalam kegiatan usaha ternak Kambing Senduro antara lain yaitu pembersihan kandang, pemberian pakan, penanganan penyakit. Pada umumnya peternak membersihkan kandang dua kali yaitu pada pagi dan sore hari. Pemberian pakan hijauan dan tambahan berbedabeda antar peternak yaitu ada yang satu kali dan juga ada yang dua kali dalam sehari. Takaran dalam pemberian pakan tambahan juga berbeda antar peternak mulai dari 3 ons hingga 1,5 kg. Penyakit

Tabel 2. Margin pemasaran susu Kambing Senduro

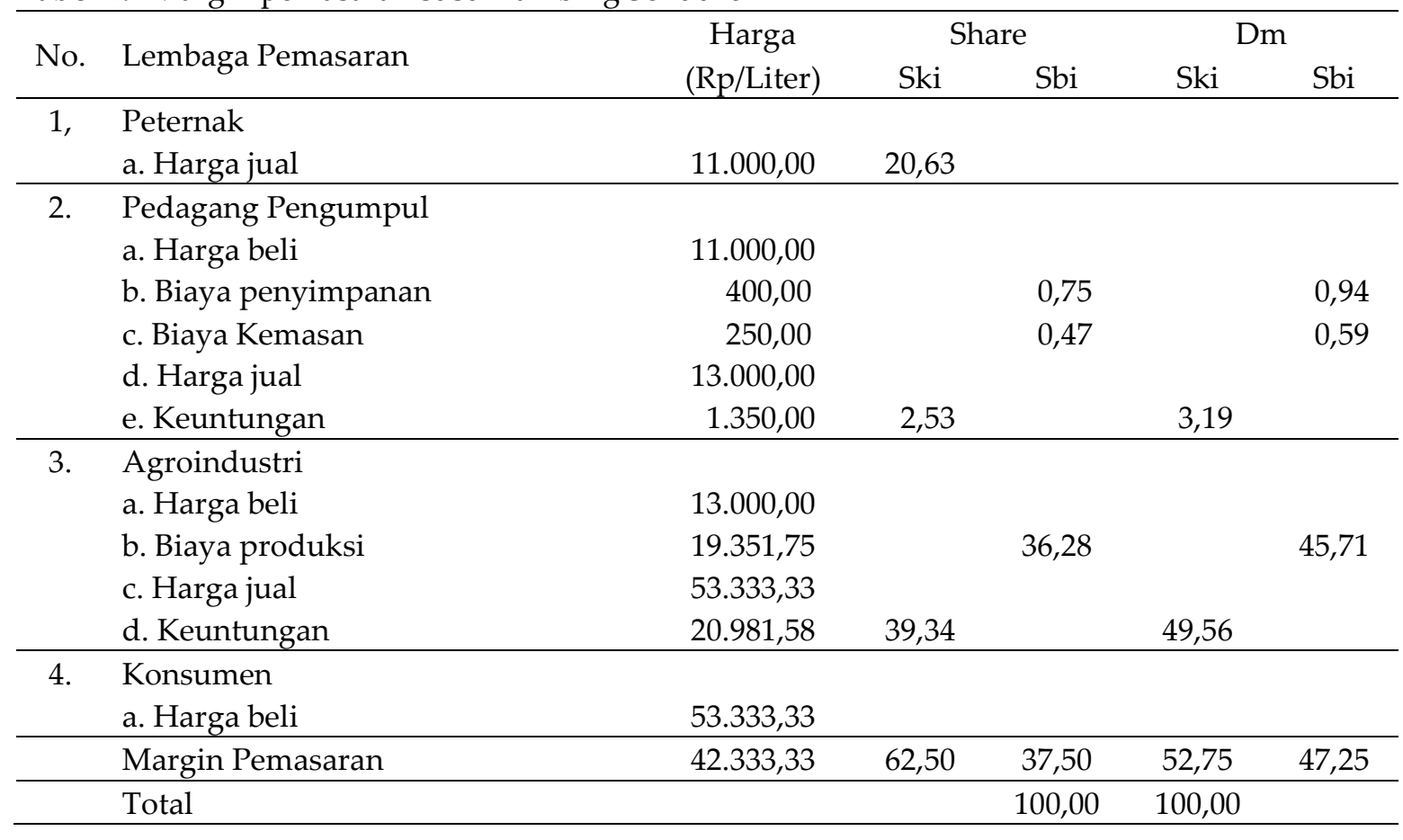


yang sering dijumpai pada usaha ternak Kambing Senduro yaitu Mastitis. Mastitis merupakan penyakit radang pada kelenjar ambing yang dapat disebabkan oleh bakteri atau jamur yang bersifat pathogen [17]. Penanganan penyakit mastitis yaitu dengan pengobatan dari dokter hewan.

3. Subsistem pengolahan

Susu Kambing Senduro pada umumnya memiliki karakteristik mudah rusak, sehingga tidak memiliki masa simpan yang lama dan harus diberi penanganan khusus agar produk susu sampai ke tangan konsumen dalam keadaan baik. Proses pengolahan pada susu Kambing Senduro ini, dapat meningkatkan nilai tambah dengan melakukan pengolahan susu Kambing Senduro menjadi susu pasteurisasi, yogurt dan kefir sehingga dapat meningkatkan nilai jual suatu produk.

Pada olahan susu pasteurisasi di Agroindustri Goatzilla dalam satu kali proses produksi dibutuhkan bahan baku susu segar sebanyak 10 liter, sehingga dapat menghasilkan 10 liter susu pasteurisasi yang kemudian dikemas menjadi 40 kemasan botol $250 \mathrm{ml}$. Harga 1 liter bahan baku susu Kambing Senduro yang semula sebesar Rp 13.000,00 per liter setelah diolah menjadi susu pasteurisasi harga jualnya menjadi $\mathrm{Rp} 40.000,00$ per liter. Dengan demikian, nilai tambah yang didapatkan dari setiap liter bahan baku susu Kambing Senduro adalah $\mathrm{Rp}$ 14.912,79 dengan rasio nilai tambah sebesar 37,28\%. Pendapatan tenaga kerja didapatkan dari perkalian koefisien tenaga kerja dengan upah tenaga kerja per hari dalam sekali proses produksi, yaitu sebesar Rp 2.500/liter atau 16,76\%. Dari penjualan susu pasteurisasi, keuntungan yang diperoleh pengusaha Agroindustri Goatzilla adalah sebesar Rp. 12.412,79/liter atau $31,03 \%$.

Pada olahan yogurt di Agroindustri Goatzilla dalam satu kali proses produksi dibutuhkan bahan baku susu segar sebanyak 15 liter, sehingga dapat menghasilkan 30 liter yogurt yang kemudian dikemas menjadi 120 kemasan botol $250 \mathrm{ml}$. Harga 1 liter bahan baku susu
Kambing Senduro yang semula sebesar Rp 13.000,00 per liter setelah diolah menjadi yogurt harga jualnya menjadi Rp 40.000,00 per liter. Dengan demikian, nilai tambah yang didapatkan dari setiap liter bahan baku susu Kambing Senduro adalah Rp $44.773,53$ dengan rasio nilai tambah sebesar 55,97\%. Pendapatan tenaga kerja didapatkan dari perkalian koefisien tenaga kerja dengan upah tenaga kerja per hari dalam sekali proses produksi, yaitu sebesar Rp 3.333,33/liter atau 7,44\%. Dari penjualan yogurt, keuntungan yang diperoleh pengusaha Agroindustri Goatzilla adalah sebesar Rp. 41.440,19/liter atau $51,80 \%$.

Pada olahan kefir di Agroindustri Goatzilla dalam satu kali proses produksi dibutuhkan bahan baku susu segar sebanyak 10 liter, sehingga dapat menghasilkan 10 liter kefir yang kemudian dikemas menjadi 40 kemasan botol $250 \mathrm{ml}$. Harga 1 liter bahan baku susu Kambing Senduro yang semula sebesar Rp 13.000,00 per liter setelah diolah menjadi kefir harga jualnya menjadi Rp 80.000,00 per liter. Dengan demikian, nilai tambah yang didapatkan dari setiap liter bahan baku susu Kambing Senduro adalah Rp $52.237,79$ dengan rasio nilai tambah sebesar $65,30 \%$. Pendapatan tenaga kerja didapatkan dari perkalian koefisien tenaga kerja dengan upah tenaga kerja per hari dalam sekali proses produksi, yaitu sebesar Rp 2.500/liter atau 4,79\%. Dari penjualan kefir, keuntungan yang diperoleh pengusaha Agroindustri Goatzilla adalah sebesar Rp. 49.737,79/liter atau $62,17 \%$.

4. Subsistem pemasaran

Margin pemasaran adalah merupakan selisih antara harga di tingkat pembeli dan harga di tingkat peternak [18]. Untuk mengetahui besarnya suatu keuntungan dari setiap pelaku rantai pasokan susu Kambing Senduro di Kecamatan Senduro perlu dilakukan analisis margin pemasaran. Lembaga-lembaga yang terlibat pada saluran pemasaran susu Kambing Senduro antara lain yaitu peternak, pedagang pengumpul, agroindustri, dan konsumen. 
Nilai margin pemasaran sebesar Rp. 42.333,33 per liter. Nilai tersebut merupakan nilai selisih antara harga yang dibayarkan konsumen akhir dengan harga yang diterima peternak. Peternak pada pemasaran yang dilakukannya memiliki nilai share keuntungan sebesar $20,63 \%$. Share keuntungan yang diperoleh peternak cukup ideal dengan adanya penelitian Sugiarti et al. [19], yang menyatakan bahwa besarnya keuntungan yang diperoleh peternak pada pemasaran susu pasteurisasi mendekati $20,63 \%$ yaitu $18,20 \%$. Pedagang pengumpul membeli susu Kambing Senduro dari peternak dengan harga Rp. 11.000 per liter. Biayabiaya yang dikeluarkan oleh pedagang pengumpul terdiri dari biaya penyimpanan sebesar Rp. 400 atau 0,75\% dan biaya kemasan sebesar Rp. 250 atau $0,47 \%$. Pedagang pengumpul melakukan pemasaran produknya berupa susu segar yang telah dikemas dengan harga jual Rp. 13.000 sehingga keuntungan yang diperoleh sebesar Rp. 1.350 atau 2,53\%.

Lembaga lain yang terlibat pada saluran pemasaran susu Kambing Senduro yaitu agroindustri. Agroindustri membeli susu Kambing Senduro dari pedagang pengumpul dengan harga Rp. 13.000 per liter. Biaya-biaya yang dikeluarkan oleh agroindustri yaitu hanya biaya produksi sebesar Rp. 19.351,75 atau 36,28\%. Agroindustri melakukan pemasaran produknya berupa susu olahan yang telah dikemas dengan harga jual Rp. 53.333,33 sehingga keuntungan yang diperoleh sebesar Rp. 20.981,58 atau 39,34\%.

Distribusi margin digunakan untuk mengetahui tingkat kemerataan pembagian keuntungan yang diterima masing-masing lembaga pemasaran susu Kambing Senduro. Nilai share keuntungan distribusi marjin pada pedagang pengumpul memiliki nilai 2,53 dan share keuntungan distribusi marjin pada agroindustri memiliki nilai 39,34. Pembagian keuntungan bagi masingmasing lembaga pemasaran yang terlibat dalam saluran pemasaran tergolong tidak merata karena selisih dari distribusi margin keuntungan terlampau jauh yaitu melebihi dari 5\%. Pembagian keuntungan yang tidak merata pada saluran pemasaran disebabkan karena jumlah biaya yang dikeluarkan serta harga jual yang ditentukan masing-masing lembaga berbeda-beda. Hal ini sesuai dengan penelitian Sugiarti et al. [19], yang menyatakan bahwa tidak meratanya keuntungan yang diperoleh masingmasing lembaga pemasaran yaitu sebesar $2,08 \%$ untuk pedagang pengumpul serta $19,16 \%$ untuk industri pengolah.

5. Subsistem sarana penunjang

Subsistem sarana penunjang yaitu kegiatan yang menyediakan jasa bagi agribisnis ternak seperti perbankan, asuransi, transportasi, penyuluhan, puskesnak, kebijakan pemerintah, lembaga pendidikan dan penelitian, dan lain-lain [20]. Sarana penunjang dalam agribisnis Kambing Senduro di Kecamatan Senduro Kabupaten Lumajang didukung oleh pemerintah daerah Kabupaten Lumajang. Pemerintah daerah sebagai sarana penunjang yaitu Dinas Pertanian dan Dinas Perdagangan. Dinas Pertanian telah melakukan kegiatan penyuluhan tentang budidaya dan pembibitan Kambing Senduro yang baik dan benar agar peternak memiliki bibit dan indukan yang berkualitas. Dinas Perdagangan telah melakukan pelatihan pemasaran online, pelatihan kemasan produk, pelatihan peningkatan mutu produk serta fasilitasi merk produk.

Pemodelan untuk penguatan kelembagaan korporasi pada usaha ternak Kambing Senduro di Kecamatan Senduro, Kabupaten Lumajang

Pembangunan sistem kelembagaan terintegrasi dari sektor hulu hingga ke sektor hilir merupakan kunci keberhasilan dalam pengembangan usaha ternak Kambing Senduro di Kecamatan Senduro Kabupaten Lumajang. Hal tersebut tercantum dalam Peraturan Menteri Pertanian Republik Indonesia Nomor 18/PERMENTAN/RC.040/ 4/2018 tentang Pedoman Pengembangan Kawasan Pertanian Berbasis Korporasi Petani. Dalam menjalankan suatu usaha pasti akan menemui yang namanya hambatan baik 
disektor hulu hingga disektor hilir. Salah satu cara untuk mengatasi beberapa permasalahan tersebut yaitu perlu adanya koordinasi dan sinergi antar pihak yang terlibat dalam agribisnis Kambing Senduro. Pihak yang terlibat dalam agribisnis Kambing Senduro antara lain peternak, kelompok ternak, pedagang pengumpul, agroindustri, pemerintah daerah, lembaga keuangan, dan pendidikan tinggi. Pemodelan usaha ternak Kambing Senduro di Kecamatan Senduro Kabupaten Lumajang disajikan pada Gambar 1.

Peran dari masing-masing pihak yang terdapat pada model tersebut antara lain:

1. Dinas Pertanian

Dinas Pertanian melalui Bidang Peternakan dan Kesehatan Hewan mempunyai tugas yaitu: 1) merumuskan dan menyusun kebijakan dibidang perbibitan dan produksi ternak, 2) memberikan petunjuk teknis dibidang perbibitan (SNI) dan produksi ternak (GFP), 3) merencanakan kebutuhan dan penyediaan bibit ternak, dan 4) melaksanakan pendampingan, monitoring dan evaluasi pelaksanaan kegiatan dibidang perbibitan dan produksi ternak.

2. Dinas Perdagangan

Dinas Perdagangan melalui Bidang Perindustrian mempunyai tugas yaitu: 1) merumuskan dan menyusun kebijakan dibidang industri, 2) memberikan petunjuk teknis dibidang industri (GMP), 3) menyusun pedoman teknis dan melaksanakan pengembangan teknologi industri, 4) menyusun pedoman teknis dan melaksanakan kegiatan peningkatan

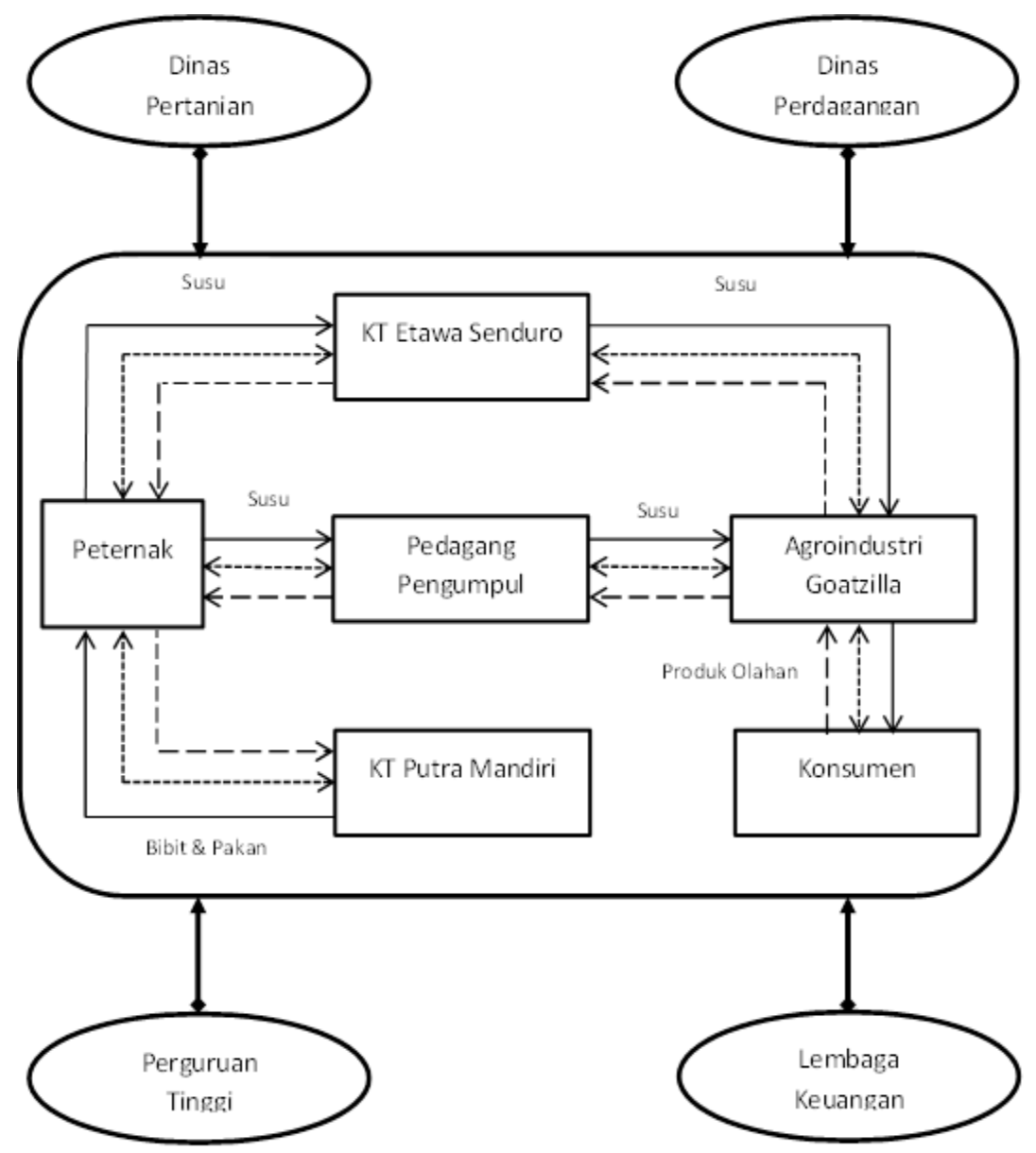

Keterangan

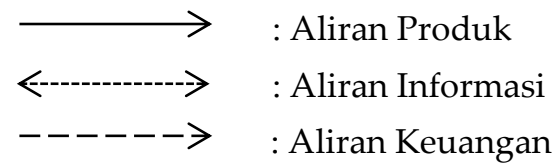

Gambar 1. Pemodelan usaha ternak Kambing Senduro 
kualitas dan diversifikasi produk industri, 5) menyusun pedoman teknis dan melaksanakan kegiatan pengembangan kreatifitas dan inovasi industri meliputi pengembangan produk, desain dan kemasan, dan 6) melaksanakan pendampingan, monitoring dan evaluasi pelaksanaan kegiatan dibidang industri.

3. Peternak

Peternak sebagai pelaku agribisnis disektor hulu mempunyai tugas yaitu: 1) perlu meningkatkan skala usaha untuk peningakatan produksi susu, 2) melaksanakan budidaya Kambing Senduro yang baik dan benar sesuai Good Farmer Practice, 3) aktif mengikuti penyuluhan atau pelatihan yang dilaksanakan oleh dinas, perguruan tinggi dan lembaga keuangan, 4) perlu mengupayakan untuk melakukan pengadaan input produksi yang telah disediakan kelompok ternak Putra Mandiri terutama untuk bibit dan pakan Kambing Senduro.

4. Kelompok Ternak

Kelompok ternak sebagai pelaku agribisnis disektor hulu mempunyai tugas yaitu: 1) melaksanakan program kerja atau kegiatan yang sesuai dengan apa yang dibutuhkan anggota kelompok, 2) pengurus melaksanakan tupoksi yang telah disepakati bersama dengan baik dan benar, 3) memfasilitasi dan menyediakan saprodi baik pakan, bibit, dll untuk seluruh anggota kelompok, dan 4) menggunakan bantuan dari pemerintah dengan optimal.

5. Pedagang Pengumpul

Pedagang Pengumpul sebagai pelaku agribisnis disektor hilir mempunyai tugas yaitu: 1) membeli susu peternak sesuai dengan harga pasar, 2) melakukan kewajiban pembayaran tepat waktu berdasarkan kesepakatan dari peternak, 3) melakukan proses pengemasan dan penyimpanan di freezer supaya susu tidak cepat rusak, dan 4) berusaha memenuhi setiap permintaan susu segar terutama untuk agroindustri.

6. Agroindustri

Agroindustri sebagai pelaku agribisnis disektor hilir mempunyai tugas yaitu: 1) melakukan proses pengolahan susu dengan benar dan jika memungkinkan menerapkan Good Manufacturing Practice, 2) aktif mengikuti pelatihan seperti manajemen pembiayaan usaha, peningkatan mutu produk, serta merk dan kemasan produk, 3) aktif ikut serta dalam bazar yang dilaksanakan oleh instansi, perusahaan, dll, dan 4) intensif dalam melakukan promosi di sosial media.

7. Lembaga keuangan

Lembaga keuangan sebagai lembaga penunjang mempunyai tugas yaitu: 1) memfasilitasi dan menyediakan modal dalam kegiatan usaha dan 2) memberikan keringanan dalam penentuan suku bunga.

8. Perguruan Tinggi

Perguruan tinggi sebagai lembaga penunjang mempunyai tugas yaitu: 1) memberikan pendampingan manajemen pengembangan usaha yang baik dan benar baik di usaha ternak maupun di proses pengolahan produk olahan susu, dan 2) mensosialisasikan beberapa alternatif pakan yang dapat meningkatkan produksi susu dengan penggunaan teknologi pengolahan pakan.

\section{KESIMPULAN}

Sistem agribisnis Kambing Senduro meliputi: 1a) Subsistem input produksi terdiri dari bibit, pakan, dan tenaga kerja, 1b) Subsistem usaha ternak terdiri dari pembersihan kandang, pemberian pakan dan penanganan penyakit, 1c) Subsistem pengolahan menjadi susu pasteurisasi, yogurt, dan kefir memiliki nilai tambah yang positif, 1d) Subsistem pemasaran terdiri dari peternak, pedagang pengumpul dan agroindustri, 1e) Subsistem sarana penunjang didukung oleh Pemerintah Daerah Kabupaten Lumajang. 2) Pemodelan pada usaha ternak Kambing Senduro terdiri dari lembaga utama (peternak, kelompok ternak, pedagang pengumpul, agroindustri, dan konsumen) dan lembaga pendukung (dinas pertanian dan perdagangan, perguruan tinggi, serta lembaga keuangan). 


\section{KONFLIK KEPENTINGAN}

Penulis menayatakan tidak ada konflik kepentingan dengan pihak manapun terkait materi yang ditulis dalam naskah ini.

\section{UCAPAN TERIMA KASIH}

Terima kasih kepada Fakultas Pertanian Universitas Jember dan Pemerintah Daerah Kabupaten Lumajang yang telah memberi ijin untuk melakukan penelitian ini serta penulis juga mengucapkan terima kasih kepada beberapa pihak yang telah bersedia menjadi responden yaitu peternak, ketua kelompok ternak, pedagang pengumpul, pemilik Agroindustri dan ekpert dari Badan Perencanaan Pembangunan Daerah Kabupaten Lumajang.

\section{DAFTAR PUSTAKA}

1. Saputra, J. I., Liman, dan Widodo, Y. 2016. Analisis Potensi Pengembangan Peternakan Sapi Potong di Kabupaten Pesawaran. J. Ilmiah Peternakan Terpadu. 4: 115-123. Doi: dx.doi.org/10.23960/jipt. v4i2.p\%25p.

2. Kasim, S. N., Sirajuddin, S. N., dan Irmayani. 2011. Strategi Pengembangan Usaha Sapi Perah Di Kabupaten Enrekang. J. Agribisnis. 10: 81-97.

3. Matitaputty, P. R. dan Kuntoro, B. 2010. Potensi dan Strategi Pengembangan Kawasan Peternakan Ruminansia dan Pemanfaatan Limbah Tanaman Pangan di Kabupaten Maluku Tenggara Barat. J. Peternakan 7: 70-81. Doi: dx. doi. org/ 10.24014 /jupet.v7i2.461.

4. Primasworo, R. A. dan Widyastuti, F. K. 2018. Identifikasi Pemetaan Potensi Peternakan di Kabupaten Probolinggo. J. Ilmiah Teknik Sipil dan Kimia 3: 148-157. Doi: dx.doi.org/10.33366/rekabuana.v3i2. 1048.

5. Manik, T. R., Adrianto, D. W., dan Subagiyo, A. 2013. Kajian Pengembangan Kawasan Agropolitan Seroja Kabupaten Lumajang. J. Tata Kota \& Daerah 5: 65-76.

6. Intano, F. T. dan Madarisa, F. 2018. Identifkasi Permasalahan yang Dihadapi oleh Anggota Forum Silaturahmi Peternak
Kambing di Sumatera Barat. J. Peternakan Indonesia. 20: 181-192. Doi: doi.org/10.25077/jpi.20.3.181-192.2018.

7. Batubara, A., Nasution, S., Subandriyo, Inounu, I., Tiesnamurti, B., dan Anggraeni, A. 2016. Kambing Peranakan Etawa. IAARD Press, Jakarta.

8. Ismail, F. 2018. Statistika untuk Penelitian Pendidikan dan Ilmu-Ilmu Sosial. Edisi Pertama. Prenadamedia Group, Jakarta.

9. Rosaliza, M. 2015. Wawancara Sebuah Interaksi Komunikasi dalam Penelitian Kualitatif. J. Ilmu Budaya 11: 71-79. Doi: doi.org/10.31849/jib.v11i2.1099.

10.Zellatifanny, C. M. dan Mudjiyanto, B. 2018. Tipe Penelitian Deskripsi dalam Ilmu Komunikasi. J. Diakom 1: 83-90. Doi: doi.org/10.17933/diakom.v1i2.20.

11. Soetriono, Soejono, D., Zahroza, D. B., Maharani, A. D., dan Amam. 2019. Strategi Pengembangan dan Diversifikasi Sapi Potong di Jawa Timur. J. Ilmu \& Teknologi Peternakan Tropis 6: 138-145. Doi: dx.doi.org/10.33772/jitro.v6i2.5571.

12. Perdana, R. A., Emawati, S., dan Sari, A. I. 2015. Analisis Pemasaran pada Usaha Mikro Kecil Menengah Kerajinan Kaligrafi Kulit Kambing di Kecamatan Sukoharjo Kabupaten Sukoharjo. Sains Peternakan 13: 80-91. Doi: doi.org/10.20961/ sainspet.v13i2.11480.

13. Wahyuningsih, S. 2007. Pengembangan Agribisnis Ditinjau dari Kelembagaan. Mediaagro. 3: 9-20. Doi: dx.doi.org/ 10.31942/md.v3i1.537.

14. Rasminati, N. 2013. Grade Kambing Peranakan Etawa pada Kondisi Wilayah yang Berbeda. Sains Peternakan. 11: 43-48. Doi: doi.org/10.20961/sainspet.v11i1.4856.

15. Yunus, A. 2012. Panduan Budidaya Kambing Etawa. Pustaka Baru Press, Yogyakarta.

16. Moeljanto, R. D. dan Wiryanta, B. T. W. 2002. Khasiat \& Manfaat Susu Kambing: Susu Terbaik dari Hewan Ruminansia. Agromedia Pustaka, Jakarta.

17. Sevitasari, A. P., Effendi, M. H., dan Wibawati, P. A. 2019. Deteksi Mastitis Subklinis pada Kambing Peranakan Etawah di Kelurahan Kalipuro, Banyuwangi. J. Medik Veteriner 2: 72-75. Doi: 10.20473/jmv.vol2.iss2.2019.72-75. 
18. Koesmara, H., Nurtini, S., dan Budisatria, I. G. S. 2015. Faktor-Faktor yang Mempengaruhi Margin Pemasaran Sapi Potong dan Daging Sapi di Kabupaten Aceh Besar. Buletin Peternakan. 39: 57-63. Doi: doi.org/10.21059/ buletinpeternak .v39i1.6160.

19. Sugiarti, S., Sriyoto, dan Gusfarina, D. S. 2007. Analisis Nilai Tambah Dan Pemasaran Susu Sapi Pada Usaha Sapi
Perah Di Kecamatan Selupu Rejang Kabupaten Rejang Lebong. J. Agrisep. 6: 119. Doi: doi.org/10.31186/agrisep.6.1.49-67. 20. Prihatiningrum, D. N. 2013. Penerapan Sistem Agribisnis Peternakan Kambing Jawa Randu dalam Kerangka Pengembangan Wilayah Kecamatan Karangpucung, Kabupaten Cilacap. J. Wilayah \& Lingkungan. 1: 141-156. Doi: doi.org/10.9767/bcrec.\%25v.\%25i.131.\%25p 